Original Research Article

\title{
A surveillance study of cutaneous adverse drug reactions in a tertiary care teaching hospital in India
}

\author{
Vandana Badar*, Vidisha Vivek Parulekar, Priti Garate
}

Department of Pharmacology, Indira Gandhi Government Medical College, Nagpur, Maharashtra, India

Received: 12 September 2018

Revised: 20 October 2018

Accepted: 25 October 2018

*Correspondence to:

Dr. Vandana Badar,

Email: drvandanabadar@ gmail.com

Copyright: (C) the author(s), publisher and licensee Medip Academy. This is an openaccess article distributed under the terms of the Creative Commons Attribution NonCommercial License, which permits unrestricted noncommercial use, distribution, and reproduction in any medium, provided the original work is properly cited.

\begin{abstract}
Background: Skin is one of the most common targets of adverse drug reactions (ADRs) The practice of pharmacovigilance all over the world is $5 \%$ whereas in India, it is below $1 \%$. Hence, the purpose of our study is to monitor and analyze the suspected cutaneous adverse drug reactions (ACDRs) reported at our tertiary care teaching hospital, to characterize the nature and predictability, severity and preventability of ACDRs and identify most common drugs causing cutaneous ACDRs so that they can be given cautiously and with keen surveillance.

Methods: An observational study was conducted in patients attending outpatient and inpatient department for a period of 3 years. All ACDRs of patients were referred by health care professionals and the diagnosis were made by concern doctors. The recorded data was filled in the ADR form obtained from pharmacovigilance program of India (2011) and Central Drug Standard Control Organization (CDSCO) website.

Results: Out of 1399 ADR reports analyzed, 564 reports (40.31\%) were of ACDRs, female to male ratio was 0.85 . Redness (44.32\%) was most common symptom, followed by itching $(44.14 \%)$ and rash (19.14\%). Antimicrobials $(43.97 \%)$, NSAIDS (21.63\%), Anti-retroviral therapy drugs (13.65\%) were common groups. As per WHO-UMC causality classification, modified Hartwig and Siegel severity scale, Thornton and Schumock preventability scale, ACDRs were probable, mild and possibly preventable respectively.

Conclusions: Effective ADR monitoring plays a role in safety of medicines. So, awareness regarding early diagnosis and prompt treatment should be created among the health care professionals and reporting of ACDRs should be regularly practiced by all the departments.
\end{abstract}

Keywords: Cutaneous adverse drug reactions, Modified Hartwig severity scale, Thornton-Schumock preventability scale, WHO-UMC causality classification

\section{INTRODUCTION}

Skin is one of the most common targets of adverse drug reactions (ADRs). ${ }^{1}$ An adverse drug reaction (ADR) is defined by the World Health Organization (WHO) as "any noxious, unintended or undesired effect of a drug that occurs at doses used in humans for prophylaxis diagnosis, therapy or modification of physiological functions". ${ }^{2}$ Cutaneous drug reactions is defined as any undesirable change in the structure or function of skin, its appendages or mucous membranes, encompassing all adverse events related to drug eruption regardless of etiology. ${ }^{3}$ Several large cohort studies infer that acute adverse cutaneous drug reactions (ACDRs) affected about $3 \%$ of hospital inpatients. ${ }^{4}$ These reactions commonly occur a few days to 4 weeks after commencement of treatment. Majority of ACDRs are benign, however, few can be severe and can increase morbidity and mortality. The Council for International Organization of Medical Sciences (CIOMS) had defined serious ADRs as "fatal or life-threatening, or require prolonged hospitalization, or result in persistent or significant disability or incapacity". 5 Fixed drug eruptions are most frequent type of ACDRs quoted in few studies 
with incidence rate of $24 \%$ to $29 \% .^{6,7}$ Though eruption is the only manifestation, death can result from exfoliative dermatitis, erythema multiforme, Steven-Johnson syndrome (SJS), toxic epidermal necrolysis (TENs). ${ }^{8}$ Early diagnosis and detection of ACDRs can reduce the duration of hospital stay of the patients and treat the patients promptly so that the outcome of the patient turns out to be positive.

ACDRs can either be immunological that is IgE-dependent reactions, immune-complex dependent reactions, cytotoxic-drug induced reactions, cell-mediated reactions which are due to drug itself or its reactive metabolite or some concurrent medication or they can be nonimmunological which is more common type including pseudo-allergic reactions caused by non-immune mediated degranulation of pro-inflammatory cells. According to Thompson and Rawlins classification, 80\% of reactions are Type A (predictable), rest are Type B (unpredictable), Type C (related to chronic therapy), Type D (due to teratogenesis and carcinogenesis). ${ }^{9}$ Due to various morphological patterns of the skin lesions, the diagnosis moreover relies towards clinical observation.

As many of the ACDRs are mild to moderate, there is insufficient data of ACDRs due to under-reporting as some may go un-noticed and others may get reversed after drug withdrawal or treated expeditiously. The practice of pharmacovigilance all over the world is $5 \%$ whereas in India, it is still in infancy that is below $1 \% .{ }^{10}$ Hence, the purpose of our study is to monitor and analyze the suspected cutaneous adverse drug reactions (ACDRs) reported at our tertiary care teaching hospital, to characterize the nature and predictability, severity and preventability of ACDRs and identify most common drugs causing cutaneous ACDRs so that they can be given cautiously and with keen surveillance.

\section{METHODS}

A longitudinal, retrospective, observational, study was conducted in patients attending outpatient and inpatient department of a tertiary care government teaching hospital of India for a period of 3 years that is between January 2014 to January 2017. All suspected ADRs of patients in the hospital were referred by health care professionals and the diagnosis were made by concern doctors of respective department. The data was recorded as per spontaneous ADR reporting system. The recorded data was filled in the ADR form obtained from pharmacovigilance program of India (2011) and Central Drug Standard Control Organization (CDSCO) website. ${ }^{11}$ Patient's age and gender, type of ADR, history of diseases, starting date of ADR, suspected drug causing ADR, primary source of ADR, concomitant medicines given, reporting person's initials (doctor, nursing staff in charge, resident, physician, pharmacist) etc. were noted. The data was analyzed as symptom-wise classification of ACDRs, classification of ACDRs and causative drugs, group-wise classification of ACDRs, department-wise classification of ACDRs, most common anti-microbials causing ACDRs, top 10 drugs causing ACDRs and types of ACDRs according to Thompson and Rawlins classification, seriousness classification of ACDRs, causality assessment was done according to WHO - UMC causality assessment criteria, severity assessment was done by Hartwig-Siegel severity scale and preventability assessment was done by modified Thornton and Schumock preventability scale. .,12-14 $^{2}$ Respective physician of the institution helped in the process and data was analyzed by using simple proportions method.

\section{RESULTS}

Out of 1399 ADR reports analyzed, 564 reports (40.31\%) were of adverse cutaneous drug reactions (ACDRs) which included from mild urticarial rash to severe Steven Johnson's Syndrome.

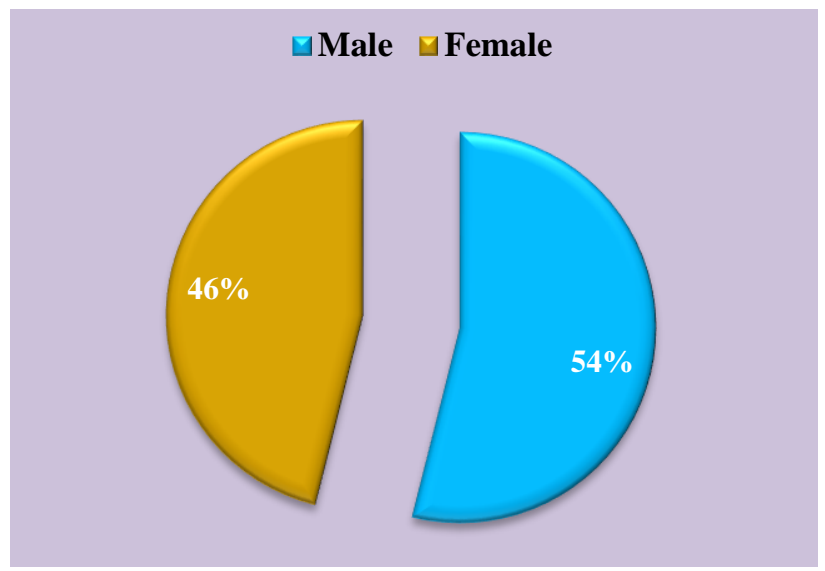

Figure 1: Gender-wise distribution of ACDRs.

Demographic data denoted a female to male ratio of 0.85 . (Figure 1) There was female preponderance $(54 \%)$ in this study.

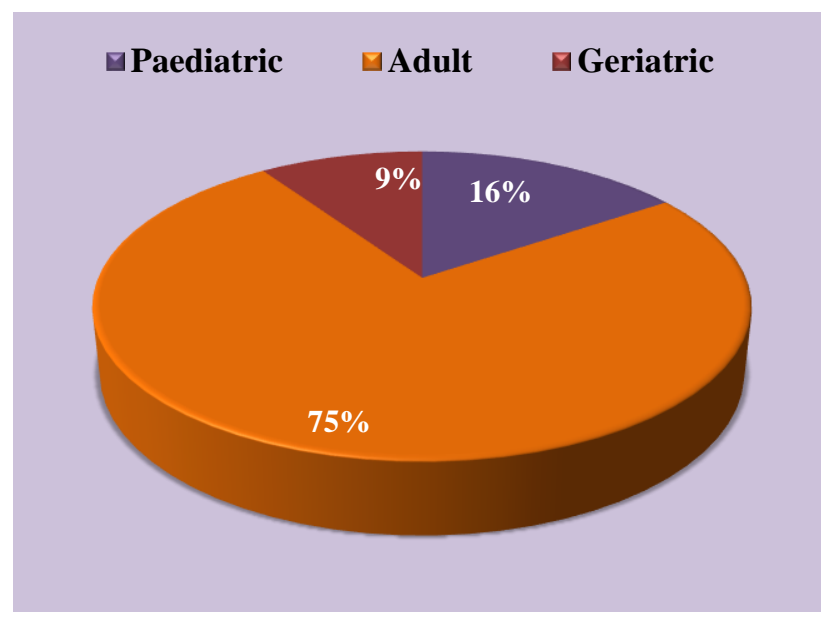

Figure 2: Age-wise classification of ACDRs.

According to age-wise classification of ACDRs, maximum cases were adults (19-65years) with $75 \%$ 
followed by paediatric age group (less than 18 years) with $16 \%$ and lastly the geriatric age group (more than 65 years) with $9 \%$.

According to cutaneous symptom-wise analysis, redness (44.32\%) was most common symptom, followed by itching $(44.14 \%)$ and rash $(19.14 \%)$ (Table 1$)$.

Table 1: Symptom-wise classification of ACDRs.

\begin{tabular}{|lll|}
\hline Symptom & Number & Percentage (\%) \\
\hline Redness & 250 & 44.32 \\
\hline Itching & 249 & 44.14 \\
\hline Rash & 108 & 19.14 \\
\hline Eruptions & 47 & 8.33 \\
\hline Acne & 44 & 7.8 \\
\hline Hyperpigmentation & 24 & 4.25 \\
\hline Hair loss & 20 & 3.54 \\
\hline Nail discolouration & 04 & 0.7 \\
\hline Hirsutism & 02 & 0.35 \\
\hline
\end{tabular}

ACDRs- Adverse cutaneous drug reactions

Table 2: Classification of ACDRs.

\begin{tabular}{|c|c|c|c|}
\hline & $\begin{array}{l}\text { Causative } \\
\text { drugs }\end{array}$ & Number & $\begin{array}{l}\text { Percentage } \\
(\%)\end{array}$ \\
\hline \multicolumn{4}{|l|}{ I. Common } \\
\hline Pruritis & $\begin{array}{l}\text { Doxycylline, } \\
\text { Amoxicillin- } \\
\text { clavulanic } \\
\text { acid }\end{array}$ & 249 & 44.14 \\
\hline $\begin{array}{l}\text { Maculopapular } \\
\text { eruptions }\end{array}$ & $\begin{array}{l}\text { Amoxycillin, } \\
\text { Paracetamol }\end{array}$ & 136 & 24.11 \\
\hline $\begin{array}{l}\text { Fixed drug } \\
\text { eruptions }\end{array}$ & $\begin{array}{l}\text { Tinidazole, } \\
\text { Paracetamol }\end{array}$ & 55 & 9.75 \\
\hline $\begin{array}{l}\text { Acneiform } \\
\text { rash }\end{array}$ & $\begin{array}{l}\text { Isoniazid, } \\
\text { Naproxen }\end{array}$ & 48 & 8.51 \\
\hline $\begin{array}{l}\text { Morbilliform } \\
\text { rash }\end{array}$ & $\begin{array}{l}\text { Amoxicillin, } \\
\text { Cotrimoxazole }\end{array}$ & 42 & 7.44 \\
\hline Urticarial & $\begin{array}{l}\text { Paracetamol, } \\
\text { Diclofenac }\end{array}$ & 21 & 3.72 \\
\hline $\begin{array}{l}\text { Eczematous } \\
\text { eash }\end{array}$ & $\begin{array}{l}\text { Ampicillin, } \\
\text { Amoxicillin- } \\
\text { clavulanic } \\
\text { acid }\end{array}$ & 05 & 0.88 \\
\hline Angioedema & $\begin{array}{l}\text { Captopril, } \\
\text { Norfloxacin }\end{array}$ & 05 & 0.88 \\
\hline $\begin{array}{l}\text { Bullous } \\
\text { eruptions }\end{array}$ & $\begin{array}{l}\text { Amoxicillin, } \\
\text { Ampicillin }\end{array}$ & 03 & 0.53 \\
\hline $\begin{array}{l}\text { Anaphylactic } \\
\text { shock }\end{array}$ & Ceftriazone & 01 & 0.17 \\
\hline \multicolumn{4}{|l|}{ II. Severe } \\
\hline $\begin{array}{l}\text { Steven- } \\
\text { Johnson's } \\
\text { syndrome }\end{array}$ & $\begin{array}{l}\text { Terbinafine, } \\
\text { Nevirapine, } \\
\text { Ciprofloxacin, } \\
\text { Amoxicillin- } \\
\text { clavulanic } \\
\text { acid }\end{array}$ & 04 & 0.7 \\
\hline
\end{tabular}

ACDRs- Adverse cutaneous drug reactions, SJS- StevenJohnson's Syndrome
Table 2 is broadly classified into common ACDRs and severe ACDRs. As per classification of ACDRs, common and less severe reactions included maculopapular rash, FDE, etc. In this table, most of the cases observed were of pruritis $(44.14 \%)$ due to doxycylline and amoxicillinclavulanic acid followed by maculopapular eruptions $(24.11 \%)$ due to amoxicillin and paracetamol. However, there were four severe cases of Steven-Johnson's syndrome due to terfinafine, nevirapine, ciprofloxacin, amoxicillin-clavulanic acid.

According to group-wise classification of ACDRs, antibiotics scoring the highest number. Antimicrobials (43.97\%) mainly amoxicillin-clavulanic acid, ampicillin, amoxicillin, cotrimoxazole, ceftriazone, ciprofloxacin, NSAIDS (21.63\%) like diclofenac, paracetamol, Antiretroviral therapy drugs $(13.65 \%)$ like nevirapine, efavirenz, zidovudine were common groups showing ACDRs. Miscellaneous drugs include anti-asthmatics, histamine receptor 2 blockers, proton-pump inhibitors, anti-depressants, vitamin preparations (Figure 3).

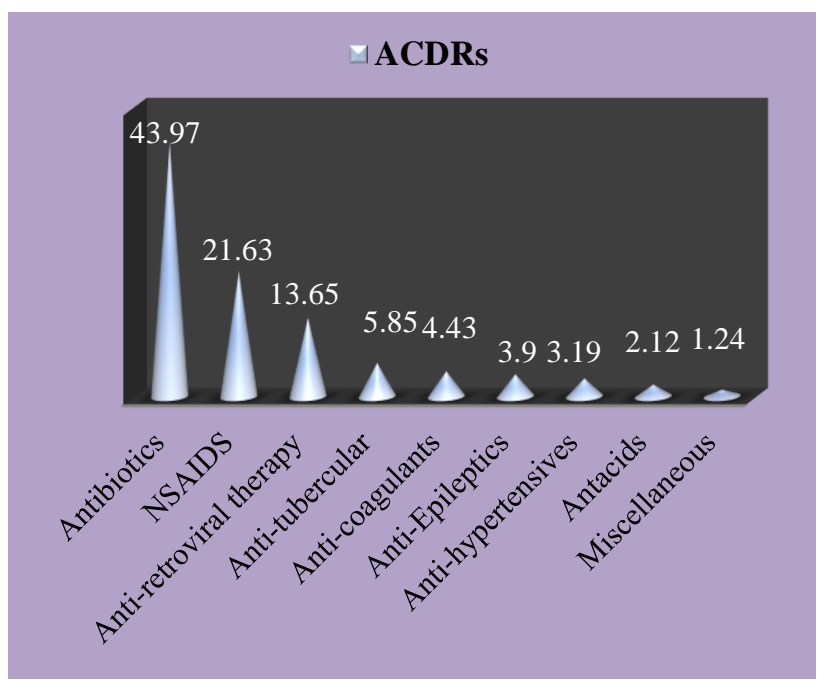

Figure 3: Group-wise classification of ACDRs.

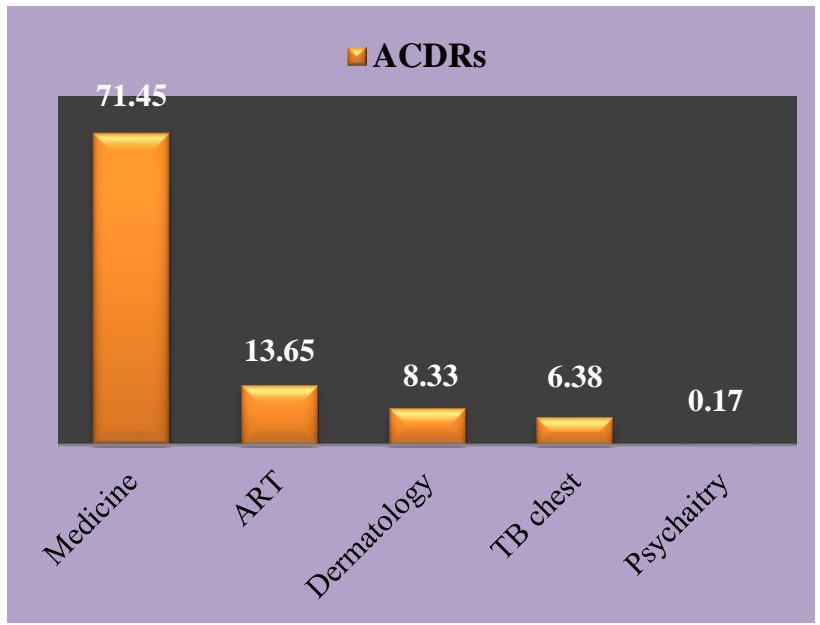

Figure 4: Department-wise classification of ACDRs. 
Medicine department reported maximum number of ACDR cases. Medicine (71.45\%) and allied departments were the ones who reported ACDRs regularly and vigilantly (Figure 4).

It was seen that among anti-microbials, ACDRs was more common with amoxicillin-clavulanic acid (18.95\%), ciprofloxacin $(14.91 \%)$, amoxicillin $(14.11 \%)$ and others (Figure 5).

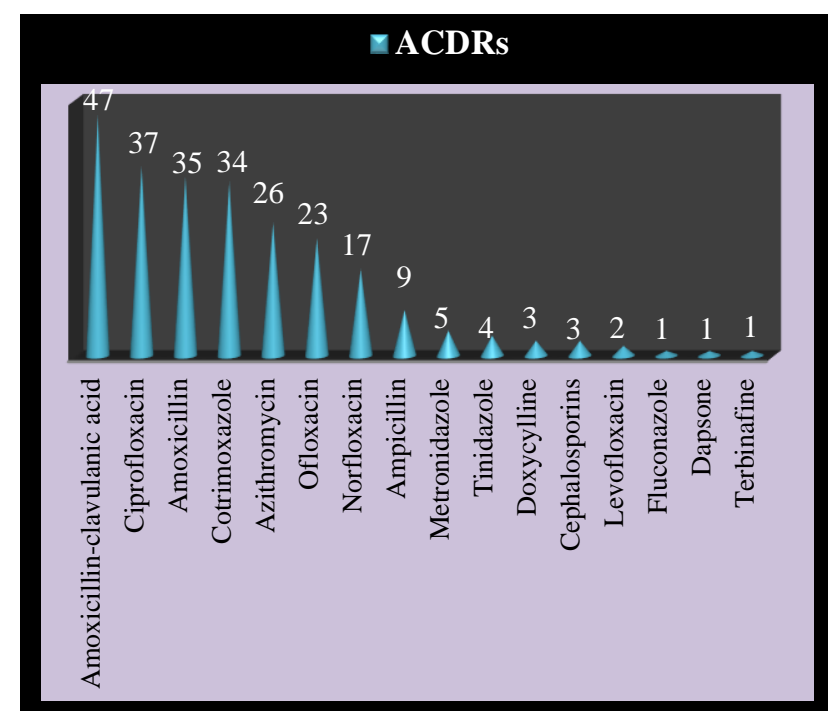

Figure 5: Most common anti-microbials causing ACDRs.

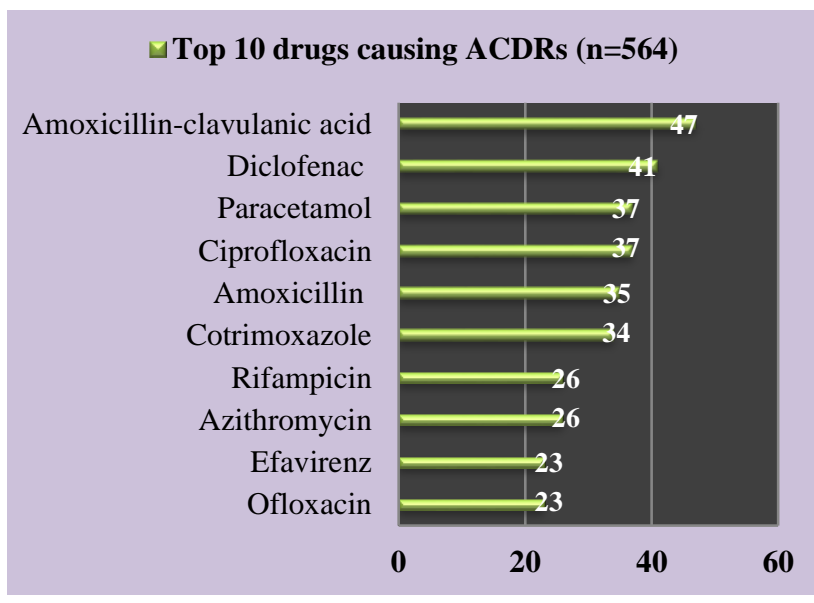

Figure 6: Top 10 drugs causing ACDRs in descending order of preference.

In this figure, amoxicillin-clavulanic acid (47 ACDRs), diclofenac (41 ACDRs), paracetamol (37ACDRs) were most common drugs.

It was seen that according to Thompson and Rawlings classification, type A (89\%) was the most common type of drug reaction observed as most of the reactions were dosedependent and predictable from the known pharmacology of the drug.

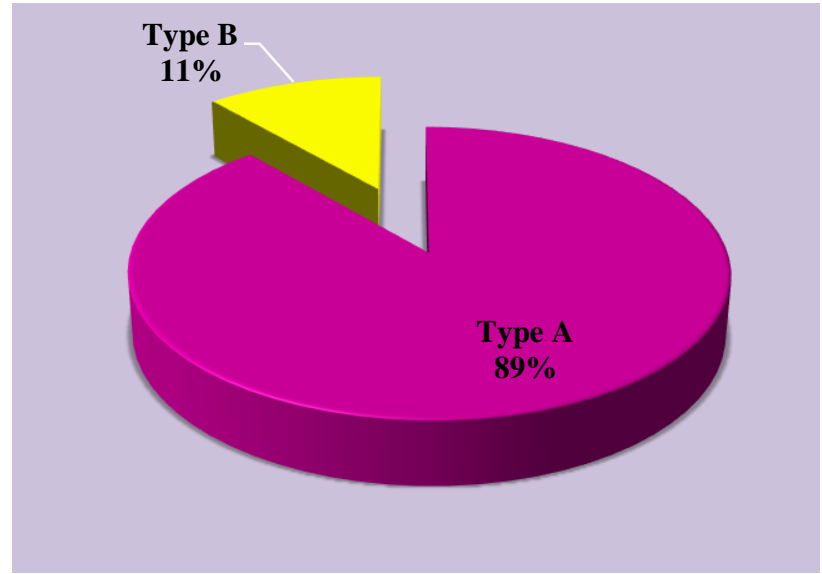

Figure 7: Thompson and Rawlins classification. ${ }^{8}$

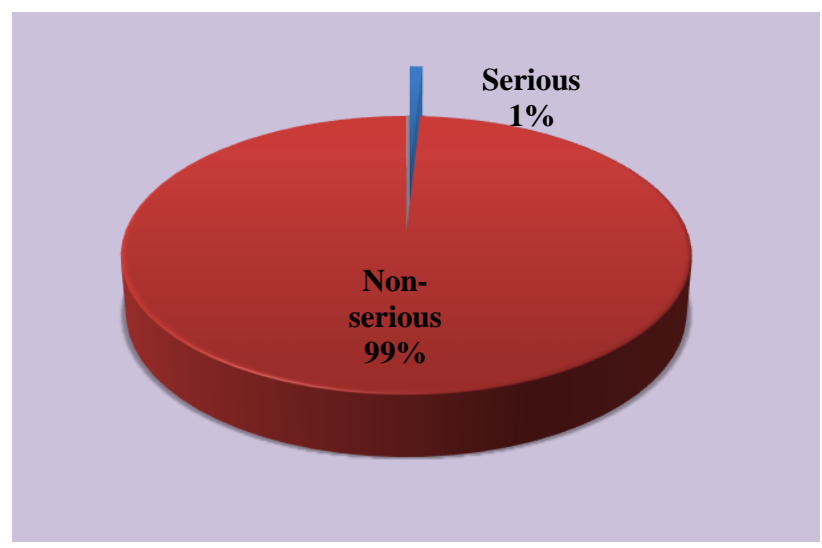

Figure 8: Seriousness classification.

As per seriousness classification, $99 \%$ were non-serious ACDRs (Figure 8). ${ }^{15}$

All ACDR reports were evaluated by WHO-UMC causality classification (Figure 9), Modified Hartwig and Siegel severity scale (Figure 10), Thornton and Schumock preventability classification (Figure 11). ${ }^{10,11}$

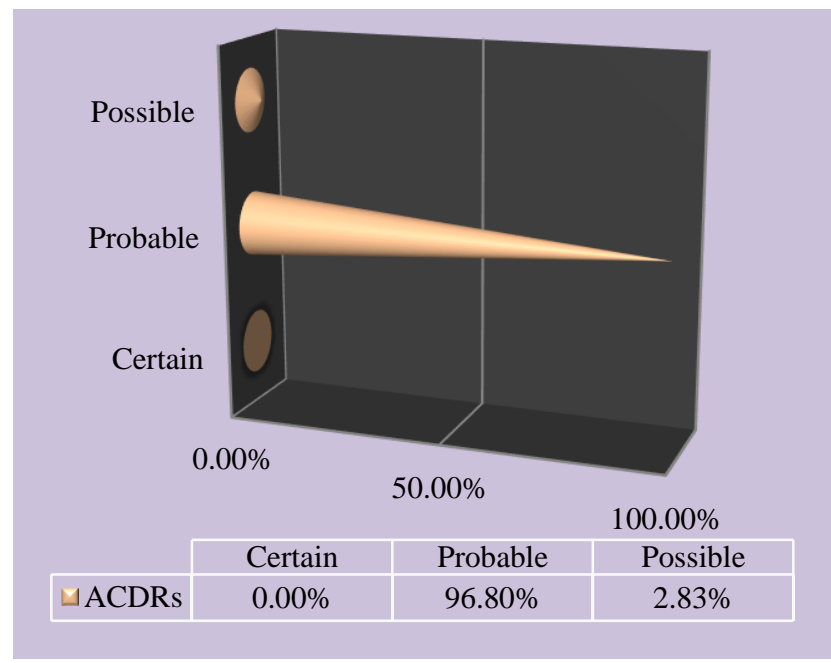

Figure 9: WHO-UMC causality classification. ${ }^{10}$ 
According to WHO-UMC classification, maximum ACDRs were of probable (96.80\%) type.

Few were of possible $(2.83 \%)$ type whereas no certain reaction was noted.

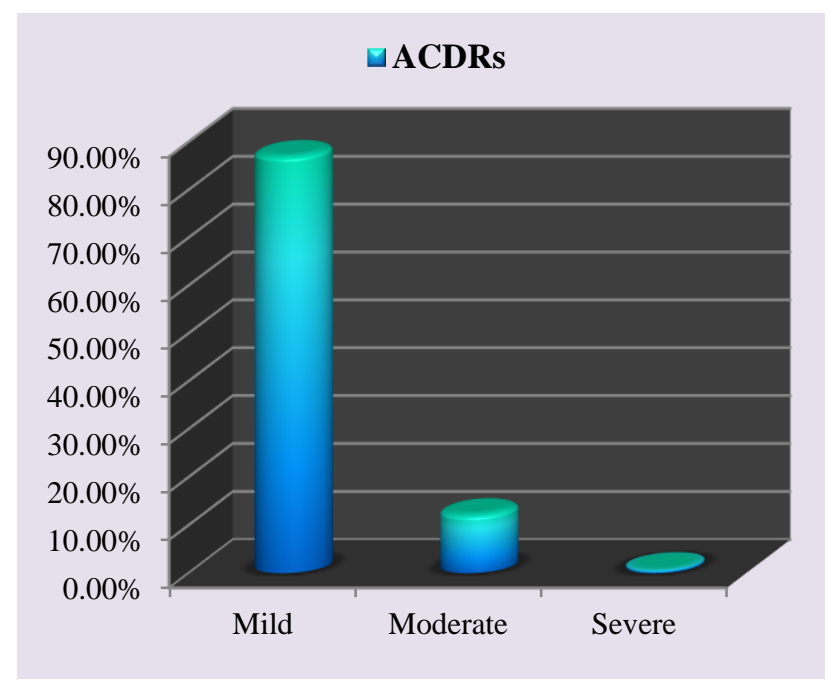
Figure 10: Modified Hartwig and Siegel
severity scale.

As per Modified Hartwig and Siegel scale, mild reactions $(87.05 \%)$ were observed in bulk number of cases. Very few cases of moderate reactions $(12.23 \%)$ and severe reactions $(0.7 \%)$ were seen.

Severe reactions included one anaphylactic reaction and four Steven-Johnson's reactions.

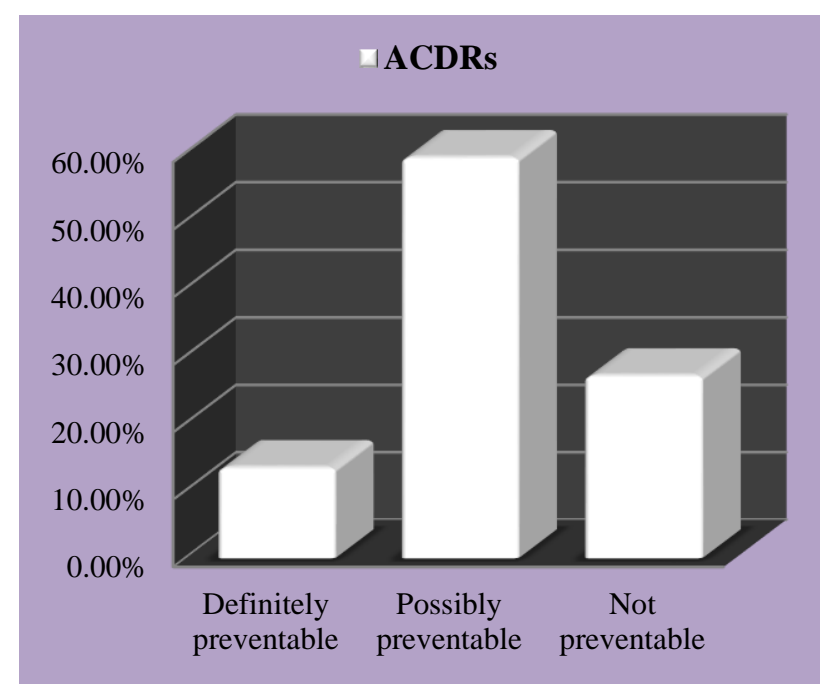

Figure 11: Thornton-Schumock's preventability classification. $^{14}$

According to Thornton and Schumock preventability classification, most reactions were classified as possibly preventable $(59.39 \%)$. Few reactions were not preventable with $27.12 \%$. Others were definitely preventable with $13.47 \%$.

\section{DISCUSSION}

The total cases of adverse cutaneous drug reactions analyzed in the period of 3 years were $564(40.31 \%$ of total reactions). ${ }^{3}$

Males showed slight predominance in this study which coincided with Agrawal et al, and not similar to Dimri et al. ${ }^{16,17}$ Most common age-group was that of adults (13-60 years) $(74.82 \%)$ which was similar to Chauhan VS study $(47 \%){ }^{18}$ This is because majority of patients coming to OPD or admitted to wards were between 20-50 age group which coincides with high Indian population in this age group.${ }^{19}$ Common symptoms of ACDRs included redness, itching, rash and eruptions, acne were seen in patients of our study. The clinical presentation of cutaneous adverse drug reactions can be due to involvement of variety of inflammatory cells like IgE-mediated allergic or anaphylactic responses, cytokines and some regulatory mechanisms which can give rise to symptoms of inflammation. Most frequent cutaneous reactions were maculopapular eruptions $(24.11 \%)$ which was consistent with Dubey AK et al, (33\%) and Patel et al, (32.39\%) as drugs known to cause exanthematic reactions like ampicillin, sulphonamides, amoxicillin are most commonly used. ${ }^{20-22}$

Other reactions included fixed drug eruptions, morbilliform eruptions, acneiform rash and urticaria. Four Steven-Johnson Syndrome (SJS) cases were reported to nevirapine, ciprofloxacin, amoxicillin-clavulanic acid and to terbinafine and 1 case was of anaphylactic shock to injection ceftriaxone. The outcome of these severe ACDRs were prolonged hospitalizations due to SJS was reported and patients recovered later. Antimicrobials and analgesics were the majority of drug groups causing ACDRs. ${ }^{23} \mathrm{~A}$ similar finding was reported in Ravichandra $\mathrm{R}$ et al, and in Sharma et al. ${ }^{24,25}$ The use of anti-microbials is increasing day by day and most of the analgesics are available over the counter. Polypharmacy is practiced to a huge extent, analgesics are prescribed on patient's demand in some of the cases. Anti-retroviral group of drugs like efavirenz, nevirapine, zidovudine, tenofovir, lamivudine, stavudine, abacavir were next common having ACDRs. These drugs showed a wide range of hypersensitivity reactions from mild morbilliform rash to severe Steven-Johnson reaction. Other groups were anti-tubercular drugs as ACDRs to first line anti-tubercular agents (rifampicin, isoniazid, pyrazinamide, ethambutol) was common. ACDRs to antiepileptic drugs like phenytoin, carbamazepine was also seen.

Amoxicillin- clavulanic acid was most common antimicrobial causing ACDRs followed by ciprofloxacin, amoxicillin and cotrimoxazole. This finding was consistent with Garg HK et al. ${ }^{26}$ 
Cutaneous eruptions including urticarial, morbilliform rash or maculopapular rashes occur $1-2 \%$ of treatment courses with amoxicillin. ${ }^{27-29}$ Cotrimoxazole is known to cause fixed drug eruption due to sulphonamide or trimethoprim component. ${ }^{30}$

According to Thompson and Rawlins classification, majority of reactions were of Type A that is predictable reactions. ${ }^{9}$ These reactions are non-immunological occurring due to side-effects, cumulation, delayed toxicity, drug interactions, overdosage or due to nonimmunological activation of effector pathway. As per seriousness classification, only $1 \%$ ACDRs were serious. ICH defines a serious ADR as any untoward medical occurrence that at any dose results in death, is lifethreatening, requires inpatient hospitalization or results in prolongation of existing hospital stay, results in persistent or significant disability/incapacity, is a medically important event or reaction. ${ }^{31}$ Seriousness is considered as a guide for defining regulatory reporting obligations. ${ }^{15}$

According to WHO-UMC causality scale, majority of cases in this study were probable $(96.8 \%){ }^{12}$ This finding was consistent with Krishna $\mathbf{J}$ et al, where majority were probable $(52.2 \%) .{ }^{32}$ Most of the cases were probable as they were unlikely to be explained by other drugs or disease, laboratory tests were abnormal which had reasonable relationship to intake of the drug, re-challenge was not done.

As per modified Hartwig-Siegel severity scale, majority of cases were mild as most of the times, suspected drug was withheld, discontinued or otherwise changed and no antidote or other treatment was required, no increase in length of hospital stay in case of inpatients and majority of reactions were from outpatient department. ${ }^{13,33,34}$

In this study, most cases were probably preventable as per Thornton and Schumock preventability scale as therapeutic monitoring was not performed, ACDR seen due to drug interactions, poor compliance was involved in ACDR and preventable measure was not prescribed or administered to the patient. ${ }^{3,14}$ The preventable reactions include reactions with previous allergic history to the drug or dose, frequency and route of administration of the drug which is not suitable for the patient's condition, toxic serum concentration of the drug suggesting that inappropriately high dose was given or drug metabolizing enzymes were inhibited or suppressed, if there was a known treatment for the adverse drug reaction. The limitations of the study were re-challenge could not be done due to ethical considerations to the patient. The results were evaluated from the data filled in ADR reporting form filled by our health-care professionals, so we cannot deny the observer bias if it has occurred as morphologically lesions may vary and are difficult to diagnose on clinical suspicion. ACDRs were reported from few departments (medicine and allied) so we could not seek the data from other departments due to underreporting.

\section{CONCLUSION}

As ACDRs are most common of adverse drug reactions, it is always better to prevent than to cure. Drugs embroiled in past reaction should be avoided, patients should be asked for previous allergies or any history of hypersensitivity to the drugs and sensitivity testing like patch tests should be done to confirm it. In case of suspected allergy, alternative medication should be used.

Thus, effective ADR monitoring plays a role in safety of medicines. So, awareness regarding early diagnosis and prompt treatment should be created among the health care professionals and reporting of ACDRs should be regularly practiced by all the departments.

\section{ACKNOWLEDGEMENTS}

Authors would like to thank to all health care professionals of their hospital for reporting ACDRs to our ADR monitoring center.

\section{Funding: No funding sources}

Conflict of interest: None declared

Ethical approval: The study was approved by the Institutional Ethics Committee

\section{REFERENCES}

1. Valeyrie-Allanore L, Roujeau JC. Mann's pharmacovigilance. $3^{\text {rd }}$ ed. Elizabeth A, Nicholus M, editors. John Wiley and Sons Ltd.; 2014:503-512.

2. World Health Organization. International Drug Monitoring: The Role of the Hospital. Geneva, Switzerland: World Health Organization; 1966. Technical Report Series No. 425. 1996:1-24.

3. Manjhi PK, Mohan L, Dikshit H, Mishra H, Kumar M, Shambhu D. IJBCP International Journal of Basic and Clinical Pharmacology Original Research Article Drug utilization pattern in dermatology outpatient department at a tertiary care hospital in Navi Mumbai. 2017;6(3):559-62.

4. Braunwald. Cutaneous Drug Reactions. Harrison Principles of Internal Medicine $19^{\text {th }}$ ed. 2015:377-385.

5. CIOMS. Harmonizing the use of adverse drug reaction terms, definition of terms and minimum requirements for their use: respiratory disorders and skin disorders. Pharmacoepidemiol Drug Saf. 1997;(6):115-27.

6. Bordet R, Gautier S, Le Louet H, Dupuis B, Caron J. Analysis of the direct cost of adverse drug reactions in hospitalised patients. Eur J Clin Pharmacol. 2001 Mar 1;56(12):935-41.

7. Thiessard F, Roux E, Miremont-Salamé G, FourrierRéglat A, Haramburu F, Tubert-Bitter P, et al. Trends in spontaneous adverse drug reaction reports to the French pharmacovigilance system (1986-2001). Drug Safety. 2005 Aug 1;28(8):731-40.

8. Breathnach S. Rook's Textbook of Dermatology Volume 4. $8^{\text {th }}$ ed. Burns T, Breathnach S, Cox N, 
Griffiths C, editors. Blackwell Publishing Ltd; 2010:75.1-75.177.

9. Rawlins M, Thompson J. Textbook of Adverse Drug Reactions. 3rd ed. Davies D, editor. Oxford. Oxford University Press; 1985:12-38.

10. Bhattacharjee P, Das L, Ghosh R, Das UK. IJBCP International Journal of Basic and Clinical Pharmacology Research Article Pattern of adverse drug reactions reported at a tertiary health care teaching hospital of Tripura. a retrospective study. 2016;5(4):1293-9.

11. Central drugs standard control organization. Protocol for National Pharmacovigilance programme [Internet]. 2014 [cited 2018 Apr 12]. Available at: http://www.cdsco.nic.in/forms/Default.aspx

12. Organization WH. The use of the WHO-UMC system for standardized case causality assessment. Uppsala Uppsala Monit Cent [Internet]. 2005;(3):2-7. Available at: http://whoumc.org/Graphics/24734.pdf\%5Cnhttp://scholar.goog le.com/scholar?hl=enandbtnG=Searchandq=intitle: $\mathrm{Th}$ e+use+of+the+WHO-

UMC+system+for+standardised+case+causality+asse ssment\#0

13. Hartwig S, Siegel J, Schneider P. Preventability and severity assessment in reporting adverse drug reactions. Am J Hosp Pharm. 1992;49:2229-32.

14. Raut AL, Patel P, Patel C, Pawar A. Preventability, Predictability and Seriousness of Adverse Drug Reactions amongst Medicine Inpatients in a Teaching Hospital: A Prospective Observational Study. Int J Pharm Chem Sci. 2012;1(3):1293-9.

15. Verma S, Gulati Y. Fundamentals of Pharmacovigilance. 1st ed. Hyderabad: Paras Medical Publisher; 2017:64-84.

16. Agrawal V, Pandey S, Gupta U. An Observational Study of Clinical Pattern of Adverse Cutaneous Drug Reactions and Causative Agents in Tertiary Health Care Center. Indian J Appl Res. 2015;5(7):523-5.

17. Dimri D. Retrospective Analysis of Pattern of Cutaneous Adverse Drug Reactions in Tertiary Hospital of Pauri Garhwal. J Clin Diagnostic Res [Internet]. 2016;1-6. Available at: http://jcdr.net/article_fulltext.asp?issn=0973-

709 xandyear $=2016$ andvolume $=10$ andissue $=5$ andpage $=$ FC01 andissn $=0973-709$ xandid $=7736$

18. Chauhan V, Chourishi A. A Study of Cutaneous Adverse Drug Reactions in Tertiary Care Hospital of Central India. Glob J Res Anal. 2016;5(1):61-2.

19. Census of India. Population composition. Census of India [Internet]. 2011;11-28. Available at: http://www.censusindia.gov.in/vital_statistics/SRS_R eport/9Chap 2 - 2011.pdf

20. Dubey AK, Prabhu S, Shankar PR, Subish P, Prabhu MM, Mishra P. Cutaneous adverse drug reactions to modern medicines and initial experiences from a spontaneous adverse drug reaction reporting program in a tertiary care teaching hospital of Western Nepal. J Pakistan Assoc Dermatologists [Internet]. 2005;15(3):222-6. https://www.scopus.com/inward/record.uri?eid=2-

s2.0-

29244439949andpartnerID=40andmd5=b684fe07b8c 8a339003be1542f161cfe

21. Patel T, Thakkar S, Sharma D. Cutaneous adverse drug reactions in Indian population: A systematic review. Indian Dermatol Online J [Internet]. 2014;5(6):76. Available at http://www.idoj.in/text.asp?2014/5/6/76/146165

22. Motgahre VM, Bajait CS, Turankar A, Pimpalkhute SA, Dholpure M. Prescription pattern and adverse drug reaction profile of drugs prescribed with focus on NSAIDs for orthopedic indications at a tertiary care hospital. 2016;3(December):178-81.

23. Patel NH, Padhiyar J, Shah YB, Dixit RK. Study of Causality, Preventability and Severity of Cutaneous Adverse Drug Reactions in a Tertiary Care Institute. 2015;1891(June):24-7.

24. Murray J, Vedavathi H, Prasad N, Dadapeer H, Revankar S. A study on cutaneous adverse drug reactions at district Mc. Gann teaching hospital, Shimoga institute of medical sciences, Shivamogga, Karnataka, India. Int $\mathbf{J}$ Basic Clin Pharmacol. 2016;5(4):1343-8.

25. Sharma R, Dogra D, Dogra N. A study of cutaneous adverse drug reactions at a tertiary center in Jammu, India. Indian Dermatol Online $\mathrm{J}$ [Internet]. 2015;6(3):168. Available at: http://www.idoj.in/text.asp?2015/6/3/168/156384

26. Garg HK, John LJ, Thomas IN, Muttappallymyalil J, Kadhum W, Sreedharan J. Cutaneous adverse drug reactions in a tertiary healthcare centre in Ajman, UAE. 2012;1(November):137-42.

27. Wise $P$, Neu H. Experience with amoxicillin: an overall summary of clinical trials in United States. J Infect Dis. 1974;129:S266-7.

28. Levine L. Quantitative comparison of adverse reactions to cefaclor versus amoxicillin in a surveillance study. Paediatr Infect Dis. 1985;4:358-61.

29. Bigby M, Jick S, Jick H, Arndt K. Drug induced cutaneous reactions. A report from Boston Collaborative Drug Surveillance Program on 15438 consecutive inpatients, 1975 to 1982 . JAMA. 1986;256:3358-63.

30. Dwari B, Bajracharya S, Gupta S, Mishra P, Palaian S, Alam K, et al. Fixed drug eruption due to cotrimoxazole: a case report. J Inst Med. 2007;28(2):6770 .

31. International Conference on Harmonisation of Technical Requirements for Registration of Pharmaceuticals for Human Use. Harmonised Tripartite Guideline: Clinical Safety Data Management: Definitions and Standards for Expedited Reporting E2a. Effic Guidel [Internet]. 1994;(October):12. Available at: http://www.ich.org/fileadmin/Public_Web_Site/ICH_ Products/Guidelines/Efficacy/E2A/Step4/E2A_Guide line.pdf

32. Krishna J, Babu GC, Goel S, Singh A, Gupta A, Panesar S, et al. A prospective study of incidence and 
assessment of Adverse Cutaneous Drug Reactions as a part of Pharmacovigilance from a rural northern Indian medical school. Int Arch Integr Med. 2015;2(6):108-15.

33. Jayanthi CR, Bedwal A, Rajarathna K. Cutaneous adverse drug reactions from a teaching hospital in Bengaluru: An observational study to determine the spectrum and outcome. Nat J Physiol Pha Pharmacol. 2017;7(5):476.

34. Borah A, Lahkar M, Singha B, Lihite RJ, Hazarika D. IJBCP International Journal of Basic and Clinical
Pharmacology Research Article To study the pattern of suspected adverse drug reactions in patients coming to the department of dermatology in Gauhati Medical College and Hospital, Guwahati, Assam, India. 2016;5(4):1655-9.

Cite this article as: Badar V, Parulekar VV, Garate P. A surveillance study of cutaneous adverse drug reactions in a tertiary care teaching hospital in India. Int J Basic Clin Pharmacol 2018;7:2439-46. 